\title{
Analysis of Psychology, Social, and Immunity in HIV/AIDS Patients Who Worked as Migrant Indonesia Worker in East Java
}

\author{
Misutarno \\ Faculty of Nursing Universitas Airlangga \\ Surabaya, Indonesia \\ misutarno@fkp.unair.ac.id
}

\author{
Nursalam \\ Faculty of Nursing Universitas Airlangga \\ Surabaya, Indonesia \\ Tintin Sukartini \\ Faculty of Nursing Universitas Airlangga \\ Surabaya, Indonesia
}

\begin{abstract}
Based on a recent study done at five Indonesia workers which infected HIV and AIDS in District Tulungagung, shows each $40 \%$ respondent is in denying and anger phase, $80 \%$ respondent in anxious social response, and $80 \%$ respondent has some CD4 under $350 / \mu$ l. Design of this research is analytic descriptive research with cross-sectional design. Major respondent psychological in bargaining level $(60 \%)$. Major respondent social in emotional, social condition $(60 \%)$. Major respondent immunity in minimum level, CD4<200/ $\mu \mathrm{l}$ (65\%). Respondent with CD4 $<200 / \mu \mathrm{l}$, is in psychological bargaining (35\%), with CD4 $<200$ and $\geq 200-350 / \mu l$ are in psychological anger and bargaining (each $20 \%$ ). Respondent with CD4 $<200 / \mu \mathrm{l}$ is in social emotion condition (35\%), CD4<200 and $\geq 200-350 / \mu l$ is in anxious and emotional psychological condition (each $20 \%$ ).
\end{abstract}

Keywords: psychological response, social response, immunity

\section{INTRODUCTION}

Medic should be aware of some factors when doing treatment to HIV-AIDS patient such social factor and psychological [1]. Social stigma and discrimination cause some psychological response, such denying, anger and depression. The consequence of HIV AIDS patient pulls themselves from society, family, friends, and circumstance affect the limitation of health service, education and subtract their human right [2][3].

This situation causes any obstacles and delaying in preventing and treatment so that HIV epidemic and number of death AIDS patient increase globally spread [2][3]. Psychosocial interference will reduce immunity of HIV AIDS patient.
East Java Public Health Office recorded 23.924 HIV AIDS patients in East Java on 2015. In District Tulungagung, there are 268 cases of HIV-AIDS on 2016 [4]. East Java Public Worker, Transmigration and Population Office via Antara news on 2011 stated the caution of spreading HIV and AIDS in East Java comes from former Indonesia worker, include women Indonesia worker.

HIV and AIDS case based on occupation is 112 Indonesia workers, female and male in East Java [4]. Based on previous studies using psychological questioner response and social, five Indonesian workers infected HIV and AIDS in District Tulungagung for psychology response two people $(40 \%)$ is in denying and anger step, and one person $(20 \%)$ in depression phase. One person in social response $(20 \%)$ emotional and four people $(80 \%)$ anxious phase. In that former studies, also done CD4 checking as immunology response, there are four people $(90 \%)$ whose CD $4<350 / \mu 1$ and one person (10\%) CD4 350/ $\mu 1$ [5].

The low psychological, social, and immunity HIV AIDS patient as Indonesian worker, has the worse impact to the patient so that increased morbidity and mortality HIV AIDS patient. Hence, to examine the condition of this patient, further research is needed. The result of these researchers could be useful to control the spread of HIV-AIDS at Indonesia worker.

\section{METHOD}

The design of this research is analytic descriptive research with cross-sectional studies. The population of the research is all Indonesia workers who have infected HIV AIDS in East Java in 2016. A sample of the research is all Indonesia workers who have infected HIV AIDS in District Tulungagung and Surabaya City (who has medical treatment at RSUD Dr. Soetomo Surabaya), taken with purposive 
sampling, which is in criteria inclusive and exclusive in 2017. Criteria of an inclusive sample of the research are Indonesia worker or former Indonesia worker, adult (21-45 years old), positive HIV and or AIDS. Criteria of the sample were HIV AIDS patient who has a medical record or is in mental disorder, sight disorder and ear.

\section{RESULTS}

Based on inclusive and exclusive criteria, found 10 Indonesia worker from Trenggalek, ten Indonesia workers from Surabaya (who has medical treatment at RSUD Dr. Soetomo Surabaya), so that total sample is 20 people. To collect data, respondent should fill the questioner. Besides, CD4 test is also done to know the number CD4 as the VISION of recent patient immunity.

TABLE 1 RESPONDENT CHARACTERISTIC

\begin{tabular}{|c|c|c|c|}
\hline No & Respondent Category & Total & $\%$ \\
\hline \multirow{3}{*}{1} & Age & & \\
\hline & 16-25 years old (young & 1 & 5 \\
\hline & $\begin{array}{l}\text { aduit) } \\
25-55 \text { years old (adult ) }\end{array}$ & 19 & 95 \\
\hline & Total & 20 & 100 \\
\hline \multirow{5}{*}{2} & Marital Status & & \\
\hline & Single & 2 & 10 \\
\hline & Married & 14 & 70 \\
\hline & Divorce & 4 & 20 \\
\hline & Total & 20 & 100 \\
\hline \multirow{4}{*}{3} & Education & & \\
\hline & Elementary School & 4 & 20 \\
\hline & Junior High School & 7 & 35 \\
\hline & Senior High School & 9 & 45 \\
\hline & Total & 20 & 100 \\
\hline \multirow{9}{*}{4} & Occupation & & \\
\hline & Farmer & 3 & 15 \\
\hline & Entrepreneur & 7 & 535 \\
\hline & Taylor & 1 & 5 \\
\hline & Housewife & 6 & 30 \\
\hline & Seller & 1 & 5 \\
\hline & Sales & 1 & 5 \\
\hline & Technician & 1 & 5 \\
\hline & Total & 20 & 100 \\
\hline
\end{tabular}

Based on Table 1, majority respondent is an adult, 26-55 years old (95\%) and married (70\%). Their last education is in Senior High School ( 45\%) and Junior High School (35\%). Their current occupation ( for former Indonesia worker ) is the majority as an entrepreneur (35\%) and housewife (30\%). Here is the data of psychological, social and immunity of respondent.
TABLE 2 PSYCHOLOGY, SOCIAL, AND IMMUNITY CONDITION OF RESPONDENT

\begin{tabular}{llll}
\hline No & Psychology Condition & Total & $\%$ \\
\hline 1 & Anger & 4 & 20 \\
2 & Bargaining & 12 & 60 \\
3 & Depression & 4 & 20 \\
& Total & 20 & 100 \\
& Social Condition & Total & $\%$ \\
1 & Emotional & 12 & 60 \\
2 & Anxious & 6 & 30 \\
3 & Social Interaction & 2 & 10 \\
& Total & 20 & 100 \\
& Immunity Condition & Total & $\%$ \\
1 & CD4<200 & 13 & 65 \\
2 & CD4 $>200-350$ & 5 & 25 \\
3 & CD4 $>350$ & 2 & 10 \\
& Total & 20 & 100 \\
\hline
\end{tabular}

Table 2 shows that majority psychological condition of the respondent is in bargaining level $(60 \%)$. It is the third phase when the patient does bargaining to them toward a condition. Same as a psychological condition, majority social status of the respondent is in the third level, emotional $(60 \%)$. The next, majority immunity condition of respondent is at the lowest level, the CD $4<200 / \mu 1(65 \%)$. It might be linked to the psychological condition, and social which is at the same level. If we link between immunity and psychological condition, the data are as follows:

TABLE 3 IMMUNITY AND PHYCOLOGICAL CONDITION OF RESPONDENT

\begin{tabular}{llcccl}
\hline No & $\begin{array}{l}\text { Immunity } \\
\text { Condition }\end{array}$ & \multicolumn{3}{c}{ Psychological condition } & Total \\
& Anger & Bargaining & Depression & \\
\hline 1 & CD4<200 & 4 & 7 & 2 & 13 \\
& & $20 \%$ & $35 \%$ & $10 \%$ & $65 \%$ \\
2 & CD4 2 & 0 & 4 & 1 & 5 \\
& $200-350$ & & $20 \%$ & $5 \%$ & $25 \%$ \\
3 & CD4 $\geq$ & 0 & 1 & 1 & 2 \\
& 350 & & $5 \%$ & $5 \%$ & $10 \%$ \\
& Total & 4 & 12 & 4 & 20 \\
& & $20 \%$ & $60 \%$ & $20 \%$ & $100 \%$ \\
\hline
\end{tabular}

Table 3 shows that respondent with CD4 $<200$ is in bargaining psychological condition (35\%). However, there is respondent with CD4 $<200 / \mu 1$ and $\geq 200-350 / \mu 1$ is also in anger and bargaining psychological condition (each 20\%).

Table 4 shows that respondent with CD4 $<200 / \mu 1$ is in emotional, social condition (35\%). However, there is also respondent with CD4 $<200$ and $\geq 200-350 / \mu 1$ is in anxious and emotional psychology condition (each $20 \%$ ). 
TABLE 4 IMMUNITY AND SOCIAL CONDITION OF RESPONDENT

\begin{tabular}{llllll}
\hline No. & $\begin{array}{l}\text { Immunity } \\
\text { Condition }\end{array}$ & \multicolumn{2}{l}{ Social condition } \\
Emotional & Anxious & $\begin{array}{l}\text { Social } \\
\text { Interaction }\end{array}$ \\
\hline 1 & CD4<200 & 7 & 4 & 2 & 13 \\
& & $35 \%$ & $20 \%$ & $10 \%$ & $65 \%$ \\
2 & CD4 $\geq$ & 4 & 1 & 0 & 5 \\
& $200-350$ & $20 \%$ & $5 \%$ & & $25 \%$ \\
3 & CD4 $\geq$ & 1 & 1 & 0 & 2 \\
& 350 & $5 \%$ & $5 \%$ & & $10 \%$ \\
& Total & 12 & 6 & 2 & 20 \\
& & $60 \%$ & $30 \%$ & $10 \%$ & $100 \%$ \\
\hline
\end{tabular}

\section{DISCUSSION}

Based on data from Worker, Transmigration and Population Office (2016), majority age of people works in productive age, 15-64 years old. It matches to respondent data which shows majority age in 25-65 years old. For education, majority respondent has passed Senior High School and Junior High School. A graduate of Senior High School is more ready to face the industry. However, for the graduation of junior high school, they are too young to face the industry. After coming back to Indonesia, respondent's occupation is entrepreneur and housewife. This entrepreneur is doing home industry such as selling and sewing.

Table 2 shows that majority psychological condition of the respondent is in bargaining level $(60 \%)$. It is the third level when people do bargaining to themselves about a condition. Experiencing a disease will build some feeling and stress, frustration, worry, anger, denying, shame, mourn, and uncertainty toward adaptation to disease. As a theory of [6], about individual psychology response in a condition: denial phase, anger phase, bargaining phase, depression and acceptance.

Bargaining phase comes after anger step. When anger goes, the patient will think and feel that their protest is useless. Feeling guilty and having good relation with God, swear to be better personality if the patient can be cured, is all the characteristic of the patient in this step [7].

This research also collects data about respondent with CD4 $<200 / \mu 1$ is in bargaining phase $(35 \%)$. However, there is also respondent with CD $<200 / \mu 1$ and $\geq 200-350 / \mu 1$ in anger and bargaining psychology condition (each 20\%). That result shows the low psychology condition (level 3 and 2 ) with low CD4 $(<200 / \mu 1)$.

In anger psychological condition, patient's behavior is characteristically linked to anger and guilt. The anger is usually directed at them then regret appears. If the family comes to visit, the patient will refuse them. This matter affects the aggressiveness [8].

Same with a psychological condition, the respondent social status is also major in the third level, emotional (60\%). Table 4 shows that respondent with CD $4<200 / \mu 1$ is in emotional, social condition (35\%). However, there is also respondent with CD4 $<200$ and $\geq 200-350 / \mu 1$ in worry and emotional condition (each 20\%). Psychosocial aspect according to Hikmat [2] divided into three aspects: first is social stigma gets depression, and negative thoughts about patient's prestige worse. Second, discriminative towards HIV AIDS injected, such as working refusal and living together will give some impact to their health. This will make patient stressful worse. Third, psychology response takes much time start from denying, anger, bargaining, and depressed affects preventing and treatment postponed.

The adaptive social response is developed based on a concept included: emotion, worry and social interaction [5]. In that condition shows in intense feeling which is shown to someone or something. This emotion appears when the patient is upset about their condition, blame on themselves or anyone, also scare of their condition.

Anxious is one of subjective feeling happens to someone especially because of experiencing something new, also happens to a patient who will get invasive surgery. The patient gets anxious because of hospitalized, treatment and a medical procedure causing them uncomfortable [9]. Anxious is emotion response implies worry, nervous, scary, uncomfortable, and some physical complaints. That condition could happen in life or unhealthy condition. Besides, anxious could effect reaction which happens continuously such as hunger, out of breath, heartbeats, sweat, headache, urinate and defecate. This feeling comes along with a desire to run from something they are worried about [10]. This condition happens because the patient gets unpredictable new experience, to accept the reality treatment result which causes patient uncomfortable, so that patient can not sleep, get a headache even limit their space. Hence, a patient with those characters is possible to have low CD4.

HIV positive in patient's body also infect some cells. HIV patient would not show sign and symptom for years. Like the way the disease, CD4 will decrease the number from 1000/ $\mu 1$ before being infected 2-10 years [2]. Based on research result by Spiritia, it had few impact at a number of CD4 is gender, age, risk, psychological stress, physical stress, and maternity. Hence, in the result of this research can not be found the specific illustration between a number of CD4 and psychology and social condition [11].

\section{CONCLUSION}

The conclusion of this result is respondent with CD4 $<200 / \mu 1$ is in bargaining psychology condition (35\%). And,there is also respondent with CD $4<200$ and $\geq 200-350 / \mu 1$ is in anger and bargaining psychological condition (each $20 \%$ ). If it is compared between CD4 and psychological condition, it shows that respondent with CD $4<200 / \mu 1$ is in emotional, social condition $(35 \%)$. Besides, there is also respondent with CD4 $<200$ and $\geq 200-350 / \mu 1$ is in anxious and emotional psychological condition (20\%).

\section{REFERENCES}

[1] N. Crepaz and G. Marks, "Towards an understanding of sexual risk behavior in people living with HIV: a review of social, psychological, and medical 
findings," Aids, vol. 16, no. 2. LWW, pp. 135-149, 2002.

[2] G. J. Stewart, Managing HIV. Sydney: Australasian Medical Publishing Company, 1979.

[3] H. Hikmat, "Zero Perlakuan Diskriminatif Terhadap Orang dengan HIV/AIDS (ODHA)," Yogyakarta, pp. $1-6,2015$.

[4] D. Eka, Analisis dan Situasi HIV AIDS Kabupaten Tulungagung. Dinkes Kab. Tulungagung: Tulungagung., 2016.

[5] Nursalam and N. D. Kurniawati, Model Asuhan Keperawatan pada Pasien HIV/AIDS. 2007.

[6] E. Kübler-Ross, On Death and Dying. New York: Simon and Schuster, 1997.

[7] C. Desmond, K. Michael, and J. Gow, "The hidden battle: HIV/AIDS in the household and community," South African J. Int. Aff., vol. 7, no. 2, pp. 39-58,
2000.

[8] C. M. Hudak and B. M. Gallo, Keperawatan Kritis, Pendekatan Holistik. (Critical Care Nursing: A Holistic Approach), 4th ed. Jakarta: EGC, 1996.

[9] J. R. Cutcliffe et al., "Understanding the risks of recent discharge: The phenomenological lived experiences - 'existential angst at the prospect of discharge,"” Crisis, vol. 33, no. 1, pp. 21-29, 2012.

[10] G. Stuart and S. Sundeen, Principles and Practice of Psychiatric Nursing. St. Louise: Mosby Year Book, 1995.

[11] Y. Spiritia, Lembar Informasi tentang HIV/AIDS untuk ODHA. 2006. 